\title{
Inhibition effect of herbs on the rancidity of soybean oil
}

\author{
Keun-Young Ryu, Ae-Gyeong Kim, Tae-Sun Kim, Hyang-Hee Lee, Kye-Won Seo, \\ Bae-Sik Cho* \\ Food Analysis Division, Health and Environment Research Institute of Gwangju, Gwangju 61986, Korea
}

\section{허브의 첨가에 의한 대두유의 산패억제 효과}

\author{
류근영 · 김애경 · 김태순 · 이향희 · 서계원 · 조배식* \\ 광주광역시 보건환경연구원 식품분석과
}

\begin{abstract}
In this study, we investigated the inhibition effect of various herbs on the rancidity of soybean oil. The antioxidant activity of herb-infused oils was evaluated by examining their total phenolic contents and DPPH radical scavenging abilities. The total phenolic contents were found to increase with addition of herbs to the soybean oil. Rosemary-infused oil (RO) exhibited the highest total phenolic contents $(77.28 \mu \mathrm{g} \mathrm{GE} / \mathrm{mL})$, followed by the lemon-balm-infused oil (LO), green-tea-infused oil (GO), and soybean oil (SO) alone (36.82, 36.66, and $21.24 \mu \mathrm{g} \mathrm{GE} / \mathrm{mL}$, respectively). Similary, the DPPH radical scavenging activity of the herb infused oil also increased. Moreover, measurements on the total polar compound (TPC) contents, acid value, and $p$-anisidine value were carried out in order to confirm the changes in the rancidity of the oils during frying. The time for the TPC content to reach $25 \%$ was confirmed to be delayed from $62 \mathrm{~h}$ for SO to $68 \mathrm{~h}, 74 \mathrm{~h}$, and $80 \mathrm{~h}$ for GO, RO, LO, respectively. Even though there were some differences between the p-anisidine and acid values, it was confirmed that the addition of herbs inhibited the rancidity of soybean oil. Therefore, the results in this study show that adding herbs to soybean oil could positively contribute to the inhibition of oxidation and rancidity.
\end{abstract}

Key words : soybean oil, herb, rancidity, total polar compounds (TPC), total phenolic contents

\section{서 론}

식용유는 음식을 만들 때 가장 빈번하게 사용되는 식품 재료 중의 한가지이다. 그 중 콩을 원료로 하는 대두유는 우리나라 식용유 생산량의 $67.7 \%$ 를 차지(1)하고 있을 만큼 대표적인 식용유지의 하나이다. 그러나 식물성 유지는 불 포화 지방산 함량이 높아 조리 과정 중 산패가 빨리 진행되 는 단점이 있으며, 특히 대두유는 linoleic acid와 linolenic $\mathrm{acid}$ 와 같은 다가불포화 지방산을 함유하고 있어 대두가 가지고 있는 lipoxygenase에 의한 변향 및 자동산화에 의한

*Corresponding author. E-mail : foodcbs@korea.kr Phone : 82-62-613-7560, Fax : 82-62-613-7567

Received 11 January 2018; Revised 29 January 2018; Accepted 13 February 2018.

Copyright (c) The Korean Society of Food Preservation. All rights reserved.
산패를 잘 일으킨다(2). 유지의 산패에 관여하는 요인으로 는 산소의 흡수에 의한 자동산화, 감광체나 일중항 산소에 의한 산화, $140-200^{\circ} \mathrm{C}$ 정도의 온도로 가열된 상태에서 발생 되는 가열산화 등이 있다(2). 최근 식용유지의 이런 산화 문제를 해결하기 위해 항산화 작용이 있다고 알려진 허브의 추출물을 첨가하여 산패를 억제하는 방법들이 많이 시도되 고 있다(3-7).

우리 주위에서 손쉽게 구할 수 있는 대표적인 허브류인 녹차(Camellia sinensis (L.) O. Kuntze)는 차나무의 잎을 가 공한 것으로 항산화 성분으로 알려진 catechin 함량이 많다 고 알려져 있으며, 종류로는 (-)-epigallocatechin gallate (EGCG)이 가장 많은 함량을 차지하고 있으며, (-)-epicatechin, (-)-epigallocatechin, (-)-(+)-catechin 등도 확인되었다 $(8,9)$. 이들 페놀성 화합물들은 lipoxygenase의 활성을 저해하는 등 지질과산화, 유리라디칼의 생성, $\mathrm{LDL}$ 산화 및 산화 스트 레스의 발생을 감소시키는 것으로 보고되고 있다 $(10,11)$. 
로즈마리(Rosmarinus officinalis L.)는 꿀풀과(Labiatae)의 상록다년초로 우리에게 가장 익숙한 허브 중 하나로 음식 조리, 약용, 향료 등 다양한 용도로 사용되고 있으며, 많은 연구에서 항산화, 지질산화 억제, 항균활성 등의 효과가 있다고 알려져 있다(12-14). 로즈마리의 주요 항산화 성분 으로는 페놀성 물질인 rosmarinic acid, carnosic acid, rosmanol 등이 보고되고 있다 $(8,15,16)$. 레몬밤(Melissa officinalis)은 민트과(Lamiaceae)의 다년생 허브로 약한 레 몬향을 풍기는 허브로 로즈마리와 같이 항산화, 항균, 항종 양 효과가 있다고 보고되고 있으며(17), 주요 성분으로는 rosmarinic acid, caffeic acid, protocatechuic acid 등이 알려져 있다 $(8,18,19)$.

지금까지 허브를 이용한 항산화 연구에서는 허브의 유용 성분을 용매 추출하여 이를 식품의 원료로 직접 첨가하거나 또는 조리과정 중에 첨가하는 방법으로 식품의 항산화와 관련된 품질 향상을 확인하는 목적으로 실험이 주로 이루어 졌고, 전처리 없이 간편한 방법으로 활용할 수 있는 방법에 관한 연구는 미비한 실정이다. 따라서 본 연구의 목적은 우리가 최근 가정에서 어렵지 않게 이용할 수 있는 녹차와 허브(로즈마리, 레몬밤)를 이용하여 항산화 성분의 추출을 위한 복잡한 과정 없이 대두유에 직접 첨가하여 침출유를 만드는 간단한 방법으로 대두유에 대한 산패 억제 효과를 확인하고자 하였다.

\section{재료 및 방법}

\section{실험재료}

실험에 사용한 대두유(Sajo Haepyo Co., Incheon, Korea) 및 치킨너겟(Harim Co., Iksan, Korea)은 시중 대형마트에서 구입하였으며, 녹차(Camellia sinensis (L.) O. Kuntze), 로즈 마리(Rosmarinus officinalis L.), 레몬밤(Melissa officinalis) 등 허브는 인터넷 쇼핑몰에서 구입하여 사용하였다. 식용 유의 가열 산화를 유도하기 위해 전기 튀김기(DK-205, Delki Co., Goyang, Korea)를 사용하였다. 실험에 사용한 Folin \& Ciocalteu's phenol regent, 2,2-diphenyl-1-picrylhydrazyl(DPPH), gallic acid 및 ascorbic acid는 시그마-알드 리치사(Sigma Aldrich Co., St. Louis, MO, USA)에서 구입하 였으며, 다른 모든 시약은 analytical grade 이상의 등급을 사용하였다.

\section{침출유 제조}

침출유는 대조군인 대두유에 녹차, 로즈마리, 레몬밤 등 3 종류의 건조된 허브를 각각 $5 \%(\mathrm{w} / \mathrm{v})$ 용량으로 첨가한 후 질소충진 하여 암소에서 상온으로 7 일간 보관하여 허브 침출유(녹차유, 로즈마리유, 레몬밤유)를 제조하였다. 보관 중에는 허브의 유용성분들의 침출을 돕기 위해 하루 2 회
각각 5 분씩 흔들어 주었다.

\section{유지의 가열 산화}

식용유지의 가열에 의한 산패를 유도하기 위해 전기 튀 김기의 온도를 $180^{\circ} \mathrm{C}$ 로 유지시키면서 매 2시간 마다 치킨너 겟을 3분씩 2회(1회분량, $100 \mathrm{~g}$ ) 연속으로 튀겨주는 것을 반복하였고, 종료시점은 Testo 270(Testo SE \& Co., KGaA, Lenzkirch, Germany)으로 측정한 값인 총 극성화합물(total polar compounds; TPC) 함량이 $25 \%$ 에 도달할 때로 하였다.

\section{총 폴리페놀 함량}

총 폴리페놀 함량은 Folin-Ciocalteu's phenol reagent가 polyphenol성 화합물에 의해 환원되어 몰리브덴 청색으로 변하는 원리를 이용하여 분석하였다 $(20,21)$. 즉 각각의 유 지 $2 \mathrm{~g}$ 을 $2 \mathrm{~mL} \mathrm{n}$-hexane에 용해시키고, 이를 methanol 2 $\mathrm{mL}$ 로 총 3회 용출시켜 모두 합한 후 농축하여 측정시료로 하였다. 각각의 측정시료 $0.5 \mathrm{~mL}$ 에 methanol $3 \mathrm{~mL}$ 를 넣어 섞어준 후 $10 \%$ Folin-Ciocalteu's regent $1 \mathrm{~mL}$ 를 넣은 다음 30 초간 voltex meter로 교반하여 충분히 반응시킨다(22). 여기에 $7 \% \mathrm{Na}_{2} \mathrm{CO}_{3}$ 용액 $2 \mathrm{~mL}$ 를 넣고 methanol을 가하여 최종 부피가 $7 \mathrm{~mL}$ 가 되게 하여 섞어준 후 30 분간 상온에서 반응시키고 UV-VIS Spectrometer(UV-2550, Shimadzu, Kyoto, Japan)를 이용하여 $750 \mathrm{~nm}$ 에서 흡광도를 측정하였 다. 총 폴리페놀 함량은 gallic acid를 표준물질로 하여 검량 선을 작성하여 계산하였고, gallic acid equivalent $(\mathrm{GE})$ 로 나타내었다.

\section{$\mathrm{DPPH}$ 라디칼 소거능}

시료의 항산화성 은 2,2-diphenyl-1-picrylhydrazyl(DPPH) radical 소거능으로 측정하였다(20,23). UV-VIS Spectrophotometer 의 $517 \mathrm{~nm}$ 파장에서 $\mathrm{DPPH}$ 용액의 흡광도가 약 1.00 이 되도 록 조정하였다. DPPH radical 소거능 측정은 $0.2 \mathrm{mM} \mathrm{DPPH}$ 용액 $2 \mathrm{~mL}$ 와 각 시료 $1 \mathrm{~g}$ 을 isooctane으로 $10 \mathrm{~mL}$ 가 되게 희석한 시험액 0-1.0 mL를 넣은 후 methanol로 최종 $4 \mathrm{~mL}$ 가 되게 혼합하고 암소에서 30 분간 반응시킨 다음 $517 \mathrm{~nm}$ 에서 측정하였다. 검량선은 $100 \mathrm{ppm}$ 으로 희석한 ascorbic acid를 이용하여 시험액과 동일하게 하여 작성하였으며, 각 유지 의 DPPH radical 소거능은 DPPH 흡광도가 $50 \%$ 감소되는 농도의 ascorbic acid equivalent(AE)로 계산하였다.

\section{총 극성화합물 함량 (TPC)}

총 극성화합물 함량은 Testo 270(Testo SE \& Co., KGaA) 을 이용하여 측정하였다 $(4,24,25)$. 즉 치킨너겟을 튀긴 직후 튀김기내 유지의 거품이 없어져 안정화 될 때 까지 약 5 분간 기다린 후 Testo 270 을 가열중인 유지 중에 직접 삽입하여 측정하였다. 
산 가

산가의 측정은 AOCS법(26)으로 측정하였다. 즉 매 2시 간 마다 튀김 후 안정화시킨 유지 $5 \mathrm{~g}$ 을 삼각플라스크에 넣고 중성의 에탄올 - 에테르혼액(1:2) $100 \mathrm{~mL}$ 를 넣어 녹이 고, 페놀프탈레인 지시약을 첨가한 후 계속 흔들어 주면서 엷은 홍색이 30초간 지속할 때까지 $0.1 \mathrm{~N} \mathrm{KOH(potassium}$ hydroxide)로 적정하였다.

\section{p-Anisidine 가 (AnV)}

$p$-Anisidine가는 Lee 등(27)의 방법에 의해 측정하였다. 이소옥탄 $25 \mathrm{~mL}$ 에 시료 $100 \mathrm{mg}(\mathrm{W})$ 을 정용하여 넣고 UV-VIS Spectrometer(UV-2550, Shimadzu)로 $350 \mathrm{~nm}$ 에서 흡광도를 측정하였으며 $(\mathrm{Ab})$, 이 용액 $2.5 \mathrm{~mL}$ 에 $0.25 \%(\mathrm{w} / \mathrm{v})$ $p$-anisidine용액 $0.5 \mathrm{~mL}$ 를 혼합하고 이를 15 분간 실온에서 반응시킨 후, $350 \mathrm{~nm}$ 에서 흡광도를 측정하였다(As). $p$-anisidine가는 다음 식에 의해 계산하였다.

$$
p \text {-Anisidine value }=\frac{25 \times(1.2 \mathrm{As}-\mathrm{Ab})}{\mathrm{W}}
$$

As : 아니시딘시약과 반응한 후의 유지시료의 흡광도 $\mathrm{Ab}$ : 유지시료의 흡광도

$\mathrm{W}$ : 유지시료의 무게, $\mathrm{g}$

\section{지방산 조성}

지방산 조성 측정은 $\mathrm{AOAC}$ 법(28)에 의해 측정하였다. 유지 $25 \mathrm{mg}$ 을 유리시험관에 넣고 $0.5 \mathrm{~N} \mathrm{NaOH} 1.5 \mathrm{~mL}$ 에 희석하여 vortex mixer(VM-10, Daihan Scientific Co., Wonju, Korea)로 30 초 동안 혼합한 후, $100^{\circ} \mathrm{C}$ heating block 에서 5 분간 가온하였다. 이를 냉각한 시료에 $14 \% \mathrm{BF} 32$ $\mathrm{mL}$ 를 넣고 교반기로 30 초 동안 교반 후, 다시 $100^{\circ} \mathrm{C}$ 에서 30 분간 가온하였다. 이어 $30-40^{\circ} \mathrm{C}$ 로 냉각한 후 이소옥탄 (isooctane) $1 \mathrm{~mL}$ 를 가하고 30초간 진탕한 후 다시 포화 $\mathrm{NaCl} 5 \mathrm{~mL}$ 를 가하여 진탕하고 이소옥탄층을 무수황산나트 륨(sodium sulfate)으로 탈수하여 시험용액으로 하였고, 이 를 분석하기 위해 GC-FID(model 7890B, Agilent, Santa Clara, CA, USA)를 사용하였다. 지방산 분리를 위해 컬럼은 HP- INNOWax ( $30 \mathrm{~m} \times 0.32 \mathrm{~nm}$ id., $0.25 \mu \mathrm{m}$, Agilent)를 사용하였다.

\section{통계분석}

본 연구에서 얻어진 결과 값은 최소 3 반복 측정하였으며, 통계분석은 IBM SPSS Statistics(20, SPSS Inc, Chicago, IL, USA)를 이용하여 처리하였다. 각 실험군 간의 유의차는 one-way ANOVA를 사용하였고, 유의성 검정은 Duncan's multiple range test를 이용한 사후분석으로 $\mathrm{p}<0.05$ 수준에서 수행하였다.

\section{결과 및 고찰}

\section{총 폴리페놀 함량}

페놀성 물질들은 항산화 효과가 있는 것으로 알려져 있 다. 본 연구에서는 대두유(대조군)와 녹차유, 로즈마리유, 레몬밤유 등 허브 침출유 각각의 산패억제 효과를 확인하기 위해 총 폴리페놀 함량을 확인하였으며, 그 결과는 Table 1 과 같다. 각 유지 중의 폴리페놀성 물질의 추출은 methanol 을 이용하였으며, 정량을 위해 gallic acid로 검량선을 작성 하여 결과값을 구하였다. 그 결과 로즈마리유의 총 폴리페 놀 함량은 $77.28 \mu \mathrm{g} \mathrm{GE} / \mathrm{mL}$ 로 4가지 유지 중 가장 높게 확인되었고, 녹차유 및 레몬밤유는 각각 $36.66,36.82 \mu \mathrm{g}$ $\mathrm{GE} / \mathrm{mL}$ 로 서로 유사하였으며, 대두유가 $21.24 \mu \mathrm{g} \mathrm{GE} / \mathrm{mL}$ 의 함량으로 가장 낮게 확인되었다. 이는 녹차, 로즈마리, 레몬 밤에 들어있는 폴리페놀성 물질들이 대두유에 의해 용출되 어 그 함량이 증가한 것으로 사료된다. Saoudi 등(4)의 실험 에서는 대두유와 $6 \%(\mathrm{w} / \mathrm{w})$ 로즈마리 침출유의 총 폴리페놀 함량을 각각 174.24 와 $376.81 \mathrm{mg} \mathrm{GE} / \mathrm{kg}$ 으로 확인하여 본 연구 결과의 값과는 큰 차이를 보였으나, 로즈마리 첨가에 의해서 총 폴리페놀 함량은 증가한 것으로 확인되어 유사한 경향을 보였다. 대두유의 총 폴리페놀 함량은 유지의 구매 장소에 따라 함량차이를 보였으며, Siger 등(29)의 결과에서 는 대두유의 총 폴리페놀 함량이 $14.8 \mathrm{mg}$ caffeic acid equivalent(CE)/ $100 \mathrm{~g}$ 이라고 보고하여 본 연구의 결과보다 낮게 확인되었다. 또한 허브자체의 총 폴리페놀 함량은 Rababah 등(30)이 열수추출로 건조된 녹차와 로즈마리가 각각 59.8, $92.5 \mathrm{mg}$ chlorogenic acid equivalent/g이라고 보고 하였고, $\mathrm{Kim}$ 등(31)은 로즈마리 열수추출물의 총 폴리페놀 함량을 $42.58 \mu \mathrm{g}$ catechin equivalent/g으로 보고하였으며, Ninfali 등(32)은 acetone:5\% perchloric acid(80:20, v/v)로 추 출한 로즈마리와 레몬밤 추출물의 총 폴리페놀 함랑을 각각 $1,377.3,434.0 \mathrm{mg} \mathrm{CE}$ equivalent $/ 100 \mathrm{~g}$ 으로 보고하여 재료의 구매 시기, 장소 및 추출용매에 따라 각각 다른 결과를 보였 다. 본 실험의 결과 대두유에 허브를 첨가함으로써 허브가 가지고 있는 항산화 활성에 관여하는 폴리페놀성 화합물이

Table 1. Total phenolic contents of various oils

\begin{tabular}{cc}
\hline Samples & $\begin{array}{c}\text { Total phenolic contents } \\
(\mu \mathrm{g} \mathrm{GE} / \mathrm{mL})^{2}\end{array}$ \\
\hline $\mathrm{SO}^{1)}$ & $21.24 \pm 1.38^{\mathrm{c} 3)}$ \\
GO & $36.66 \pm 4.28^{\mathrm{b}}$ \\
RO & $77.28 \pm 4.54^{\mathrm{a}}$ \\
LO & $36.82 \pm 4.40^{\mathrm{b}}$ \\
\hline
\end{tabular}

\footnotetext{
1) SO, soybean oil; GO, green tea infused oil; RO, rosemary infused oil; LO, lemon-balm infused oil.

${ }^{2)}$ Data are expressed as $\mu \mathrm{g}$ gallic acid equivalents $/ \mathrm{mL}$.

${ }^{3)}$ Means $\pm \mathrm{SD}(\mathrm{n}=3)$ with different letters in the column are significantly different $(\mathrm{p}<0.05)$.
} 
대두유에 침출되어 대두유의 산패를 억제하는 역할을 하는 것으로 판단된다.

\section{$\mathrm{DPPH}$ 라디칼 소거능}

2,2-Diphenyl-1-picrylhydrazyl(DPPH)는 안정한 자유라 디칼을 가지고 있는 진한 보라색의 화학물질로 다른 물질의 수소이온이나 라디칼 등의 전자를 공여 받으면 탈색되거나 옅은 노란색으로 변하며(33), 그 과정에서 최대 흡광도도 변하여 원래 최대흡수 파장에서 $\mathrm{DPPH}$ 라디칼의 환원 정도 에 따라 흡광도 값이 변하는 특징을 가지고 있다. 이를 이용 하여 특정 물질이 가지고 있는 항산화물질의 존재를 확인하 기 위한 기초적인 실험으로 많이 이용되고 있다(27,34). 본 연구에서는 유지의 농축추출물이 아닌 시험유지를 각각 $250,500,750$, 그리고 $1,000 \mu \mathrm{L}$ 로 하여 mehanol로 최종 시료량이 $1,000 \mu \mathrm{L}$ 가 되도록 조제하여 $\mathrm{DPPH}$ 라디칼 소거 능을 측정하였고, 시험 유지의 $50 \%$ 억제농도(inhibitory concentration $50 \%$; $\mathrm{IC}_{50}$ )는 $100 \mathrm{ppm}$ 의 ascorbic acid 표준용 액을 대조군으로 하여 구하였으며 그 결과는 Table 2에 각각 나타내었다. DPPH 라디칼 소거능 확인 결과 ascorbic acid의 $\mathrm{IC}_{50}$ 은 $\quad 0.03 \pm 0.00 \mathrm{mg} / \mathrm{L}$ 였고, 로즈마리유는 $59.07 \pm 0.02$, 녹차유는 $70.66 \pm 0.08$, 레몬밤유는 $71.54 \pm 0.11$, 그리고 대두유는 $72.13 \pm 0.27 \mathrm{mg} \mathrm{AE} / \mathrm{mL}$ 로 확인되어, 대조 군을 제외한 시험유지 중 로즈마리유가 가장 좋은 결과를 보였고 대두유는 가장 낮았다. 이상의 결과는 총 폴리페놀 함량과 DPPH 라디칼 소거능과 상관성이 높았다는 연구결 과 $(35,36)$ 와 일치하여, 대두유에 허브를 첨가함으로써 항산 화 활성을 증가시키는 역할을 하는 것으로 판단된다.

Table 2. DPPH radical scavenging activities (inhibition percent and $\mathrm{IC}_{50}$ ) of various oils ${ }^{1)}$

\begin{tabular}{|c|c|c|c|c|c|}
\hline \multirow{2}{*}{ Samples } & \multicolumn{4}{|c|}{ DPPH radical scavenging activity $(\%)^{3)}$} & \multirow{2}{*}{$\begin{array}{c}\mathrm{IC}_{50} \\
(\mathrm{mg} \mathrm{AE} / \mathrm{mL})^{4)}\end{array}$} \\
\hline & $250 \mu \mathrm{L}$ & $500 \mu \mathrm{L}$ & $750 \mu \mathrm{L}$ & $1,000 \mu \mathrm{L}$ & \\
\hline $\mathrm{AA}^{2)}$ & $39.58 \pm 0.39^{b}$ & $84.06 \pm 0.05^{\mathrm{a}}$ & $93.72 \pm 0.20^{\mathrm{a}}$ & $95.66 \pm 0.14^{\mathrm{a}}$ & $0.03 \pm 0.00^{\mathrm{e}}$ \\
\hline SO & $37.21 \pm 0.03^{\mathrm{c}}$ & $67.94 \pm 0.06^{\mathrm{e}}$ & $87.35 \pm 0.07^{\mathrm{e}}$ & $93.03 \pm 0.01^{\mathrm{c}}$ & $72.13 \pm 0.27^{\mathrm{a}}$ \\
\hline GO & $37.14 \pm 0.13^{\mathrm{c}}$ & $69.69 \pm 0.02^{c}$ & $88.97 \pm 0.02^{\mathrm{c}}$ & $93.26 \pm 0.01^{b}$ & $70.66 \pm 0.08^{c}$ \\
\hline RO & $46.71 \pm 0.02^{\mathrm{a}}$ & $81.21 \pm 0.04^{\mathrm{b}}$ & $92.38 \pm 0.01^{b}$ & $93.27 \pm 0.01^{b}$ & $59.07 \pm 0.02^{\mathrm{d}}$ \\
\hline LO & $37.24 \pm 0.15^{\mathrm{c}}$ & $68.49 \pm 0.04^{d}$ & $88.60 \pm 0.00^{\mathrm{d}}$ & $92.35 \pm 0.02^{\mathrm{d}}$ & $71.54 \pm 0.11^{\mathrm{b}}$ \\
\hline
\end{tabular}

${ }^{1)}$ Means \pm SD ( $\left.n=3\right)$ with different letters in the same column are significantly different ( $\mathrm{p}<0.05)$

${ }^{2}$ AA, ascorbic acid; SO, soybean oil; GO, green tea infused oil; RO, rosemary infused oil; LO, lemon-balm infused oil.

${ }^{3}$ Data were expressed as percent $(\%)$

${ }^{4}$ Data were expressed as $\mathrm{mg}$ ascorbic acid equivalents/mL (mg AE/mL).

\section{총 극성화합물 함량}

총 극성화합물(TPC) 함량은 유지의 유전상수를 측정(4) 하여 산패를 확인하는 하나의 방법이며, 유전상수는 총 극 성물질의 농도와 높은 상관성을 가지고 있다 $(34,37)$. Chen 등(25)은 testo 270 을 이용하여 대두유의 TPC 함량 측정
결과 표준시험법인 AOCS Cd 20-91(38)와 거의 유사한 결 과를 보였으며, 튀김 시간의 증가에 따라 TPC 함량이 직선 적으로 증가하였다고 보고하였다. 본 연구의 TPC 함량 결 과에서도 유지의 가열시간 및 튀김횟수의 증가에 따라 직선 적으로 증가하는 경향을 보였으며, 그 결과 값은 Table 3와 같이 확인되었다. 실험 초기 대두유와 허브 침출유의 TPC 함량은 11.3-12.0\%로 큰 차이를 보이지 않았으나, 실험 종 료시점인 $25 \%$ 함량에 도달하는 시간은 대두유가 62시간으 로 가장 빨랐고, 녹차유는 68시간, 로즈마리유는 74시간, 레몬밤유가 80시간으로 확인되었다. 대조군인 대두유와 비 교했을 때 허브 침출유가 튀김조리에 연속 사용될 경우 6-18시간(튀김 횟수로는 3-9회) 더 오래 사용 가능하다는 것을 실험적으로 확인하였다. 이는 녹차, 로즈마리, 레몬밤 과 같은 허브류 중에 들어있는 폴리페놀성 화합물과 같은 항산화물질들이 대두유에 침출되면서 대두유의 산패를 억 제하는 것으로 판단된다.

Table 3. Total polar compound (\%) content of various oils during heating at frying temperature

\begin{tabular}{ccccc}
\hline Frying time (h) & $\mathrm{SO}^{1)}$ & $\mathrm{GO}$ & $\mathrm{RO}$ & $\mathrm{LO}$ \\
\hline 0 & $\left.11.3 \pm 0.3^{\mathrm{Ga} 2}\right)$ & $11.3 \pm 0.3^{\mathrm{Ga}}$ & $11.5 \pm 0.5^{\mathrm{Ha}}$ & $12.0 \pm 0.5^{\mathrm{Ha}}$ \\
10 & $15.3 \pm 0.3^{\mathrm{Fab}}$ & $14.5 \pm 0.5^{\mathrm{Fb}}$ & $15.3 \pm 0.3^{\mathrm{Gab}}$ & $15.7 \pm 0.6^{\mathrm{Ga}}$ \\
20 & $18.6 \pm 0.2^{\mathrm{Ea}}$ & $16.2 \pm 0.3^{\mathrm{Eb}}$ & $16.2 \pm 0.3^{\mathrm{Gb}}$ & $16.2 \pm 0.3^{\mathrm{Gb}}$ \\
30 & $21.2 \pm 0.3^{\mathrm{Da}}$ & $18.2 \pm 0.3^{\mathrm{Db}}$ & $17.8 \pm 0.3^{\mathrm{Fb}}$ & $17.8 \pm 0.3^{\mathrm{Fb}}$ \\
40 & $22.0 \pm 0.5^{\mathrm{Ca}}$ & $18.8 \pm 0.6^{\mathrm{Db}}$ & $18.8 \pm 0.3^{\mathrm{Eb}}$ & $19.2 \pm 0.8^{\mathrm{Eb}}$ \\
50 & $23.5 \pm 0.5^{\mathrm{Ba}}$ & $20.3 \pm 0.8^{\mathrm{Cb}}$ & $20.8 \pm 0.8^{\mathrm{Db}}$ & $20.7 \pm 1.0^{\mathrm{Db}}$ \\
60 & $24.7 \pm 0.3^{\mathrm{Aa}}$ & $23.3 \pm 0.6^{\mathrm{Ba}}$ & $22.5 \pm 1.0^{\mathrm{Cb}}$ & $22.5 \pm 0.5^{\mathrm{Cb}}$ \\
62 & $25.2 \pm 0.3^{\mathrm{Aa}}$ & $23.5 \pm 0.5^{\mathrm{Bb}}$ & $22.3 \pm 0.6^{\mathrm{Cb}}$ & $22.3 \pm 0.3^{\mathrm{Cc}}$ \\
68 & - & $24.8 \pm 0.3^{\mathrm{Aa}}$ & $23.7 \pm 0.8^{\mathrm{Bb}}$ & $23.5 \pm 0.5^{\mathrm{Bb}}$ \\
70 & - & - & $24.5 \pm 0.5^{\mathrm{ABa}}$ & $24.0 \pm 0.5^{\mathrm{Ba}}$ \\
74 & - & - & $25.0 \pm 0.5^{\mathrm{Aa}}$ & $24.3 \pm 0.6^{\mathrm{ABa}}$ \\
80 & - & - & - & $25.2 \pm 0.3^{\mathrm{A}}$ \\
\hline
\end{tabular}

${ }^{11}$ SO, soybean oil; GO, green tea infused oil; RO, rosemary infused oil; LO, lemon-balm infused oil.

${ }^{2}$ Data were expressed percent $(\%)$; means $\pm \mathrm{SD}(\mathrm{n}=3)$ with different letters in the same column $(\mathrm{A}-\mathrm{H})$ and row $(\mathrm{a}-\mathrm{c})$ are significantly different $(\mathrm{p}<0.05)$.

산 가

유지의 산가 변화는 Table 4에 나타내었다. 초기 산가는 대두유가 $0.17 \mathrm{mg} / \mathrm{g}$, 녹차유는 $0.17 \mathrm{mg} / \mathrm{g}$, 로즈마리유는 $0.20 \mathrm{mg} / \mathrm{g}$, 레몬밤유는 $0.16 \mathrm{mg} / \mathrm{g}$ 으로 확인되어 대두유의 초기 산가가 $0.03 \mathrm{mg} / \mathrm{g}$ 이라고 보고한 Son과 $\mathrm{Kang}(39)$ 의 결과보다 높았으나, 이는 각 유지들을 동일한 조건으로 실 험하기 위해 대두유도 다른 허브유와 같이 7일간 침출하는 동일한 과정을 거치는 중 발생한 산패에 의한 것으로 사료 된다. 각 유지의 산가 변화를 튀김 시간에 따라 확인하였으 며, 그 변화 정도의 비교는 대두유의 가열 종료시점인 62시 간을 기준으로 하였고, 대두유가 $1.19 \mathrm{mg} / \mathrm{g}$ 로 확인되었다. 
허브유인 레몬밤유와 녹차유에서는 산가가 각각 $1.03,0.78$ $\mathrm{mg} / \mathrm{g}$ 으로 확인되어 허브 침출유에서 그 값이 더 낮게 확인 되었으며, TPC 함량 변화의 결과와 유사한 경향을 보였다. 하지만 로즈마리유의 경우 산가가 $1.33 \mathrm{mg} / \mathrm{g}$ 으로 허브를 첨가하지 않은 대두유의 산가보다 상대적으로 높게 확인되 어 튀김 과정 중 로즈마리유에 함유된 성분과 튀김 시 발생 한 불순물의 반응에 의한 결과로 생각되며, 이 부분의 추가 적인 연구가 필요할 것으로 판단된다. 우리가 사용하는 식 용유지는 대부분 정제된 형태로 유통되지만 참기름이나 들기름과 같은 압착유의 경유 불순물의 함량이 높고(2), 이런 이유로 식품공전에서도 산가의 기준을 정제유인 대두 유는 $0.6 \mathrm{mg} / \mathrm{g}$ 이하인 반면 압착유는 더 높게(압착올리브유 $2.0 \mathrm{mg} / \mathrm{g}$ 이하, 압착고추씨기름 $3.0 \mathrm{mg} / \mathrm{g}$ 이하, 기타 식용유 지 중 압착유는 $4.0 \mathrm{mg} / \mathrm{g}$ 이하) 설정되어 있다(40). 하지만 각 유지에 대한 산가의 일반적인 경향은 Lee와 Park(41)가 보고한 가열시간이 증가 할수록 산가가 증가하는 경향을 보여 가열시간이나 튀김횟수가 증가할수록 튀김과정 중 유지 중에 부산물이 생성되고 이는 결국 산가를 증가시킬 수 있는 요인으로 작용한다는 결과와 일치하였다. 따라서 허브의 종류에 따라 그리고 실험 과정 중 변수에 의해 결과 의 차이는 있지만 TPC 함량의 결과와 같이 허브의 첨가가 대두유의 산패 증가속도를 억제하는 것으로 확인되었다.

Table 4. Acid value of various oils during heating at frying temperature

\begin{tabular}{ccccc}
\hline Frying time (h) & $\mathrm{SO}^{1)}$ & $\mathrm{GO}$ & $\mathrm{RO}$ & $\mathrm{LO}$ \\
\hline 0 & $0.17 \pm 0.00^{\mathrm{Ga} 2}$ & $0.17 \pm 0.00^{\mathrm{Ga}}$ & $0.20 \pm 0.03^{\mathrm{Ka}}$ & $0.16 \pm 0.01^{\mathrm{Ha}}$ \\
10 & $0.31 \pm 0.04^{\mathrm{Fa}}$ & $0.26 \pm 0.03^{\mathrm{Fb}}$ & $0.33 \pm 0.00^{\mathrm{Ja}}$ & $0.24 \pm 0.01^{\mathrm{GHb}}$ \\
20 & $0.48 \pm 0.03^{\mathrm{Ea}}$ & $0.35 \pm 0.03^{\mathrm{Ec}}$ & $0.43 \pm 0.01^{\mathrm{bb}}$ & $0.34 \pm 0.01^{\mathrm{Gc}}$ \\
30 & $0.78 \pm 0.00^{\mathrm{Da}}$ & $0.43 \pm 0.03^{\mathrm{Dd}}$ & $0.61 \pm 0.01^{\mathrm{Hb}}$ & $0.56 \pm 0.05^{\mathrm{Fc}}$ \\
40 & $0.93 \pm 0.03^{\mathrm{Ca}}$ & $0.59 \pm 0.03^{\mathrm{Cd}}$ & $0.80 \pm 0.03^{\mathrm{Gb}}$ & $0.64 \pm 0.00^{\mathrm{Ec}}$ \\
50 & $1.04 \pm 0.03^{\mathrm{Ba}}$ & $0.62 \pm 0.04^{\mathrm{Cc}}$ & $1.00 \pm 0.04^{\mathrm{Fa}}$ & $0.78 \pm 0.00^{\mathrm{Db}}$ \\
60 & $1.15 \pm 0.03^{\mathrm{Aa}}$ & $0.76 \pm 0.03^{\mathrm{Bc}}$ & $1.25 \pm 0.09^{\mathrm{Ea}}$ & $0.95 \pm 0.03^{\mathrm{Cb}}$ \\
62 & $1.19 \pm 0.03^{\mathrm{Ab}}$ & $0.78 \pm 0.06^{\mathrm{Bd}}$ & $1.33 \pm 0.08^{\mathrm{Da}}$ & $1.03 \pm 0.03^{\mathrm{Cc}}$ \\
68 & - & $0.89 \pm 0.06^{\mathrm{Ac}}$ & $1.44 \pm 0.08^{\mathrm{Ca}}$ & $1.09 \pm 0.04^{\mathrm{Bb}}$ \\
70 & - & - & $1.50 \pm 0.08^{\mathrm{Ba}}$ & $1.13 \pm 0.04^{\mathrm{Bb}}$ \\
74 & - & - & $1.61 \pm 0.05^{\mathrm{Aa}}$ & $1.23 \pm 0.15^{\mathrm{Ab}}$ \\
80 & - & - & - & $1.43 \pm 0.13^{\mathrm{A}}$ \\
\hline
\end{tabular}

${ }^{1}$ SO, soybean oil; GO, green tea infused oil; RO, rosemary infused oil; LO, lemon-balm infused oil.

${ }^{2}$ Data were expressed $\mathrm{mg} / \mathrm{g}$; means $\pm \mathrm{SD}(\mathrm{n}=3)$ with different letters in the same column (A-K) and row (a-d) are significantly different $(\mathrm{p}<0.05)$.

\section{$p$-Anisidine 가}

$p$-Anisidine가(anisidine value; $\mathrm{AnV}$ )는 $p$-anisidine이 유지 중의 알데하이드인 2,4-dienal과 유사한 conjugated dienal과 반응하여 황색의 물질을 형성하는 성질을 이용한 것으로 2 차 대사산물을 이용하여 산패의 정도를 판단하는 방법으
로(7), 특히 고온 산패된 유지의 품질 평가에 주로 이용되는 시험법의로 본 연구의 결과는 Fig. 1 과 같이 확인되었다. $\mathrm{AnV}$ 는 대조군인 대두유의 경우 초기 11.2 에서 30시간 후 58.8 로 증가하여 다른 유지들보다 값이 높게 확인되었으나, 그 후 60시간 까지는 지속적인 가열에도 $\mathrm{AnV}$ 는 증감 없이 일정하였고, 가열 종료 시점인 62시간에 약간 증가하는 경 향을 보였다. 그러나 로즈마리유에서는 대두유의 경우보다 증가폭이 낮게 확인되었으며, $\mathrm{AnV}$ 는 초기 2.1에서 60시간 까지 57.0로 증가하였고, 다시 감소하는 경향을 보였다. 또 한 가열시간 동안 대두유 보다 낮은 값을 보여 $\mathrm{AnV}$ 의 상승 을 억제한 것으로 확인되었다. Saoudi 등(4)도 유지를 단순 가열하는 방식으로 $\mathrm{AnV}$ 변화를 관찰한 결과 대두유는 초기 4.38에서 6시간 후 90.32로, 로즈마리 침출유는 4.38에서 38.51로 증가하였고, 그 증가가 24시간 까지 지속적되었으 나 대두유보다 로즈마리 침출유에서 $\mathrm{AnV}$ 의 증가폭이 억제 되었다는 유사한 결과를 보고하였다. 레몬밤유는 $\mathrm{AnV}$ 의 지속적인 증가로 30 시간 이 후 대두유보다 높은 값을 보였 으나 50시간 후 최고 65.5 까지 상승하다 다시 종료 시까지 감소하여 로즈마리유와 그 경향이 유사하였다. 그러나 녹 차유는 다른 유지들과는 달리 68시간 후 82.3 까지 상승하 여 종료 시까지 지속적인 증가를 보였다.

$\mathrm{AnV}$ 의 변화는 사용하는 유지의 정제도, 첨가물의 유무 등 실험에 사용된 유지의 종류와 단순한 실험실적 가열산패 를 하였는지, 아니면 식품을 이용하여 직접 튀기는 과정을 진행하여 산패를 유도하였는지 등의 처리 방법에 따라 결과 값에 큰 차이가 있는 것으로 판단된다 $(4,7,24,34)$. 본 연구의 결과 로즈마리유가 $\mathrm{AnV}$ 및 변화가 가장 낮아 대두유의 산패를 억제하는데 유용하게 작용하는 것으로 판단된다.

\section{지방산 조성}

대두유 및 허브 침출유(녹차유, 로즈마리유, 레몬밤유) 각각의 실험 전 초기상태와 실험 종료시점의 주요 지방산 조성의 변화를 확인하고 Table 5에 나타내었다. Lee 등(34) 은 가열 전 대두유의 지방산 조성이 palmitic acid(C16:0) $10.47 \%$, stearic $\operatorname{acid}(\mathrm{C} 18: 0) \quad 4.64 \%$, oleic $\operatorname{acid}(\mathrm{C} 18: 1)$ 24.29\%, linoleic acid(C18:2) 51.19\%, rinolenic acid(C18:3) $5.83 \%$ 라고 보고하여 본 실험의 결과와 유사한 구성을 보였 고, 각 유지들 사이의 지방산 조성에 유의적으로 큰 차이는 확인되지 않았다. 그러나 가열 후 각 유지의 지방산 조성 중 포화 지방산인 $\mathrm{C} 16: 0, \mathrm{C} 18: 0$ 와 단일 불포화 지방산인 $\mathrm{C} 18: 1$ 의 함량이 증가하였고, 다가불포화 지방산인 $\mathrm{C} 18: 2$ 와 $\mathrm{C} 18: 3$ 이 감소 하였다. 이는 가열산화에 의해 불포화지방산 의 중합 또는 이중결합의 분해 등에 의하거나, 튀김과정 중 튀김식품인 치킨너겟과 튀김유의 교환반응에 의해 상대 적으로 포화지방산 함량이 증가된 것으로 생각된다. Son과 $\operatorname{Kang}(39)$ 의 보고에서도 닭고기를 튀긴 후 대두유의 지방산 조성이 본 연구에서와 유사한 변화를 보였다. 그러나 Lee와 $\operatorname{Park}(41)$ 의 결과에서는 튀김유(대두유)를 이용하여 냉동감 


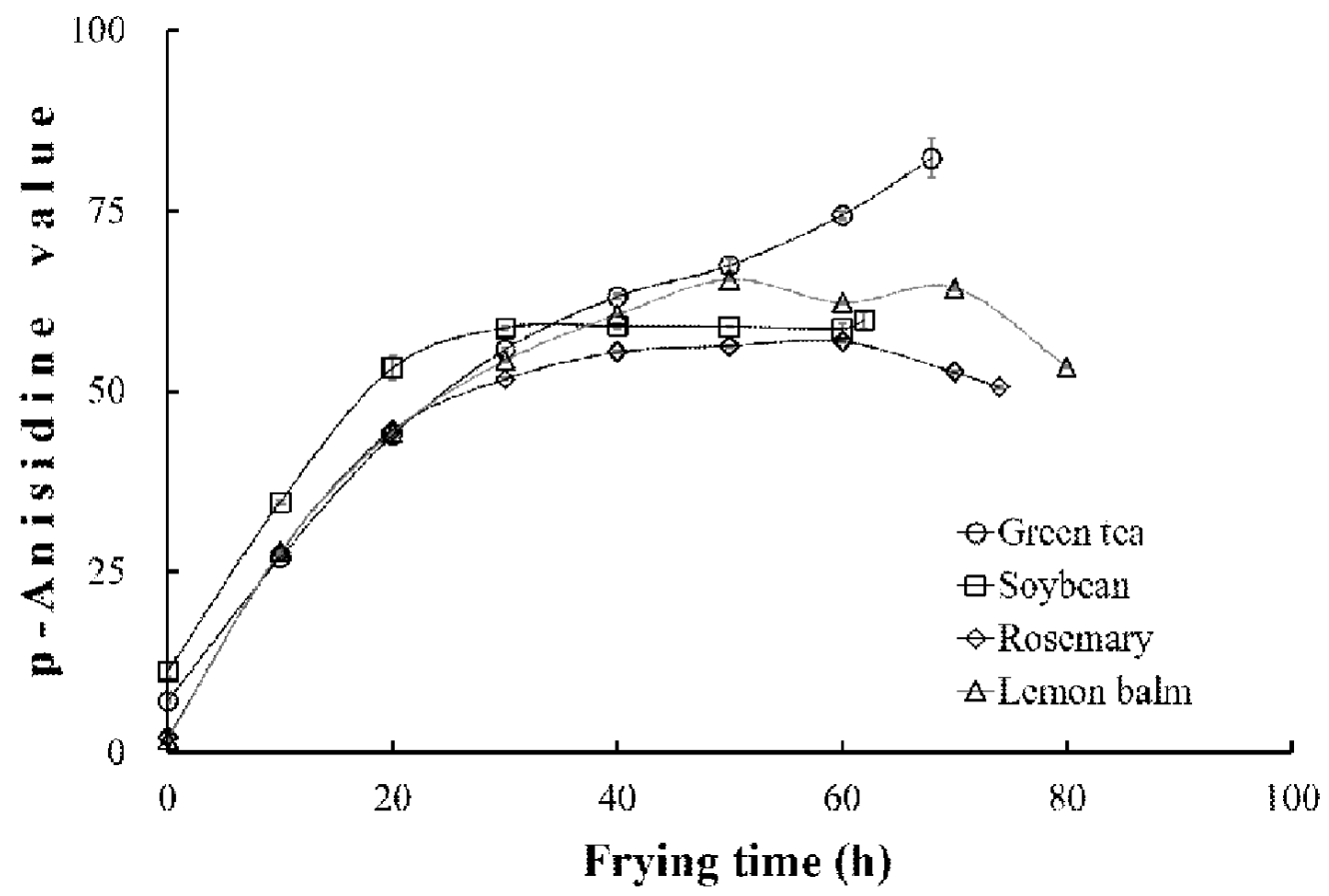

Fig. 1. Changes of $p$-anisidine value of various oils during heating at frying temperature.

Table 5. Changes of fatty acid compositions of various oils by thermal oxidation

\begin{tabular}{ccccccc}
\hline Samples & & $\begin{array}{c}\text { Palmitic acid } \\
(\mathrm{C} 16: 0)\end{array}$ & $\begin{array}{c}\text { Stearic acid } \\
(\mathrm{C} 18: 0)\end{array}$ & $\begin{array}{c}\text { Oleic acid } \\
(\mathrm{C} 18: 1)\end{array}$ & $\begin{array}{c}\text { Linoleic acid } \\
(\mathrm{C} 18: 2)\end{array}$ & $\begin{array}{c}\text { Linolenic acid } \\
(\mathrm{C} 18: 3)\end{array}$ \\
\hline \multirow{3}{*}{$\begin{array}{c}\text { First } \\
\text { (initial time) }\end{array}$} & SO & $11.27 \pm 0.06^{\mathrm{a} 2}$ & $4.40 \pm 0.09^{\mathrm{a}}$ & $23.90 \pm 0.19^{\mathrm{b}}$ & $55.09 \pm 0.20^{\mathrm{a}}$ & $5.34 \pm 0.05^{\mathrm{b}}$ \\
& GO & $11.08 \pm 0.04^{\mathrm{b}}$ & $4.21 \pm 0.05^{\mathrm{b}}$ & $24.21 \pm 0.03^{\mathrm{a}}$ & $54.98 \pm 0.07^{\mathrm{a}}$ & $5.52 \pm 0.06^{\mathrm{a}}$ \\
& RO & $11.02 \pm 0.01^{\mathrm{b}}$ & $4.35 \pm 0.03^{\mathrm{a}}$ & $23.94 \pm 0.03^{\mathrm{b}}$ & $55.23 \pm 0.06^{\mathrm{a}}$ & $5.46 \pm 0.08^{\mathrm{ab}}$ \\
& LO & $11.03 \pm 0.02^{\mathrm{b}}$ & $4.31 \pm 0.02^{\mathrm{ab}}$ & $23.94 \pm 0.02^{\mathrm{b}}$ & $55.25 \pm 0.05^{\mathrm{a}}$ & $5.46 \pm 0.06^{\mathrm{b}}$ \\
\hline \multirow{2}{*}{ Last } & SO & $14.74 \pm 0.09^{\mathrm{b}}$ & $4.59 \pm 0.02^{\mathrm{ab}}$ & $27.27 \pm 0.11^{\mathrm{b}}$ & $49.07 \pm 0.07^{\mathrm{b}}$ & $4.35 \pm 0.06^{\mathrm{a}}$ \\
(final time) & GO & $13.97 \pm 0.10^{\mathrm{c}}$ & $4.49 \pm 0.02^{\mathrm{b}}$ & $27.19 \pm 0.11^{\mathrm{b}}$ & $50.03 \pm 0.11^{\mathrm{a}}$ & $4.32 \pm 0.05^{\mathrm{a}}$ \\
& RO & $16.29 \pm 0.11^{\mathrm{a}}$ & $4.85 \pm 0.21^{\mathrm{a}}$ & $27.13 \pm 0.03^{\mathrm{b}}$ & $47.90 \pm 0.31^{\mathrm{c}}$ & $3.84 \pm 0.05^{\mathrm{b}}$ \\
& LO & $16.52 \pm 0.08^{\mathrm{a}}$ & $4.72 \pm 0.02^{\mathrm{ab}}$ & $27.51 \pm 0.04^{\mathrm{a}}$ & $47.32 \pm 0.05^{\mathrm{d}}$ & $3.92 \pm 0.05^{\mathrm{b}}$ \\
\hline
\end{tabular}

${ }^{1)}$ SO, soybean oil; GO, green tea infused oil; RO, rosemary infused oil; LO, lemon-balm infused oil.

${ }^{2}$ Means $\pm S D(n=3)$ with different letters in the same column are significantly different $(\mathrm{p}<0.05)$.

자를 튀긴 후 oleic acid가 감소되었고, linoleic acid와 linolenic acid가 증가하는 반대의 결과를 보였는데 이는 튀 김 재료의 차이로 인한 영향으로 판단된다. 대두유와 허브 침출유의 지방산 조성을 비교했을 때 로즈마리유와 레몬밤 유에서 불포화지방산의 조성 변화가 더욱 두드러지게 나타 났으나, 이는 불포화도가 증가할수록 산화 속도가 빠르다 고 한 Stirton 등(42)의 보고에서와 같이 상대적으로 높은 다가불포화 지방산 함량과, 유지의 가열시간의 차이(가열 시간, 레몬밤유 80시간 > 로즈마리유 74시간 > 녹차유 68시 간 > 대두유 62시간) 등 복합적인 원인에 의한 결과로 판단 된다.

\section{요 약}

본 연구는 항산화 성분이 있다고 알려진 녹차, 로즈마리, 레몬밤을 이용하여 대두유의 튀김 중 산패 억제 가능성을 확인하고자 하였다. 허브의 복잡한 추출과정 없이 대두유 에 침유시키는 방법으로 침출유를 제조하였고, 항산화 효 과를 확인하기 위해 총 폴리페놀 함량과 DPPH 라디칼 소거 능을 측정하였다. 그 결과 허브 침출유에서 대두유보다 항 산화 활성이 증가되는 것으로 확인되어 항산화제의 첨가 없이 허브의 첨가만으로도 항산화 효과를 증가시키는 것으 로 확인되었다. 튀김과정중 산패의 정도를 확인하기 위해 
총 극성화합물 함량(TPC)과 산가, $p$-anisidine가를 측정하 였다. 튀김 과정 중 모든 유지의 총 극성화합물 함량은 지속 적인 증가를 보였으며, $25 \%$ 도달 시점은 대두유가 62 시간 으로 산패가 가장 빨랐고, 허브 침출유에서는 레몬밤유(80 시간) > 로즈마리유(74시간) > 녹차유(68시간) 순으로 총 극성화합물의 생성 억제가 확인되었다. 산가는 유지의 가 열산화 과정 중 생성된 유리지방산을 측정하는 방법으로 모든 유지에서 튀김시간의 증가에 따라 상승하는 경향을 보여 $\mathrm{TPC}(\%)$ 의 경향과 유사하였다. 그러나 로즈마리유가 52 시간 경과 후 부터 $1.05 \mathrm{mg} / \mathrm{g}$ 으로 대두유 $(1.04 \mathrm{mg} / \mathrm{g})$ 보다 더 증가하여, 허브의 종류에 따른 차이를 확인해 볼 필요성 이 있을 것으로 판단된다. $p$-Anisidine가는 대부분 증가하다 일정 시간 후 감소하는 경향을 보였으며, 로즈마리유에서 가장 증가폭이 낮았다. 그러나 산가가 가장 낮았던 녹차유 는 가열시간이 증가하는 동안 지속적으로 상승하여 가열 종료 시 82.3으로 가장 높은 결과를 보였다. 유지의 산패에 관여하는 성분들은 다양하여 여러 측정 방법들을 사용하여 종합적인 판단에 의해 평가하여야 한다. 따라서 항상화 활 성과 산패도의 결과를 종합해 볼 때 허브의 첨가가 대두유 의 산패를 억제하는데 기여하는 것으로 판단되며, 각각의 허브들이 측정 방법들에 어떤 작용을 하는지에 대한 추가적 인 연구가 필요할 것으로 생각된다.

\section{감사의 글}

이 논문은 2017년 광주광역시 보건환경연구원 연구사업 으로 수행되었음.

\section{References}

1. aT (2014) 2014 Survey on current status of processed food subdivision market (Household cooking oil market). Agro-Fisheries \& Food Trade Corporation, Naju, Korea. p 35-38

2. Kim DH (2010) Food chemistry. Tamgudang Co., Seoul, Korea, p 775-902

3. Chammem N, Saoudi S, Sifaoui I, Sifi S, Person M, Abderraba M, Moussa F, Hamdi M (2015) Improvement of vegetable oils quality in frying conditions by adding rosemary extract. Ind Crops Prod, 74, 592-599

4. Saoudi S, Chammem N, Sifaoui I, Bouassida-Beji M, Jimenez IA, Bazzocchi IL, Silva SD, Hamdi M, Bronze MR (2016) Influence of Tunisian aromatic plants on the prevention of oxidation in soybean oil under heating and frying conditions. Food Chem, 212, 503-511
5. Chung HJ (1999) Antioxidative effect of ethanolic extracts of some teamaterials on red pepper seed oil. J Korean Soc Food Sci Nutr, 28, 1316-1320

6. Choi EM, Yoon HK, Yoon KJ, Koo SJ (2000) Effect of spices and herbs on the oxidation of the heated oil according to storage period. J East Asian Soc Dietary Life, 10, 274-280

7. Kim US, Choi EM, Koo SJ (2002) Effects of the addition of vegetables on oxidized frying oil. Korean J Soc Food Cookery Sci, 18, 557-561

8. Charles DJ (2012) Antioxidant properties of spices, herbs and other sources. Springer, Springer Science+Business Media, New York, NY, USA, p 65-75, 371-376, 495-507

9. Choi HA, Kim MR, Hong J (2011) Evaluation of cytotoxic properties of tea polyphenols in intestinal cells treated with over-the-counter drugs. Korean J Food Sci Technol, 43, 641-647

10. Hong J, Smith TJ, Ho CT, August DA, Yang CS (2001) Effects of purified green and black tea polyphenols on cyclooxygenase and lipoxygenase dependent metabolism of arachidonic acid in human colon mucosa and colon tumor tissues. Biochem Pharmacol, 62, 1175-1183

11. Coimbra S, Castro E, Rocha-Pereira P, Rebelo I, Rocha S, Santos-Silva A (2006) The effect of green tea in oxidative stress. Crin Nutr, 25, 790-796

12. Chae IG, Kim HJ, Yu MH, Kim HI, Lee IS (2010) Antioxidant and antibacterial activity of commercially available herbs in Korean markets. J Korean Soc Food Sci Nutr, 39, 1411-1417

13. Chen Q, Shi H, Ho CT (2011) Effects of rosemary extracts and major constituents on lipid oxidation and soybean lipoxygenase activity. J Am Oil Chem Soc, 69, 999-1002

14. Lee SG, Lee EJ, Park WD, Kim JB, Choi SW (2011) Antioxidant and anti-inflammatory activities of extracts from Korean traditional medicinal prescriptions. Korean J Food Sci Technol, 43, 624-632

15. Richheimer SL, Bernart MW, King GA, Kent MC, Bailey DT (1996) Antioxidant activity of lipid-soluble phenolic diterpenes from rosemary. J Am Oil Chem Soc, 73, 507-514

16. Ahmed SG, Ahmed FS (2015) Antioxidant properties of rosemary and its potential uses as natural antioxidant in dairy products-a review. Food Nutr Sci, 6, 179-193

17. Binello A, Cravotto G, Boffa L, Stevanato L, Bellumori M, Innocenti M, Mulinacci N (2017) Efficient and selective green extraction of polyphenols from lemon balm. C R Chimie, 20, 921-926 
18. Carnat AP, Carnat A, Fraisse D, Lamaison JL (1998) The aromatic and polyphenolic composition of lemon balm (Melissa officinalis L. subsp. Officinalis) tea. Pharm Acta Helv, 72, 301-305

19. Guginski G, Luiz AP, Silva MD, Massaro M, Martins DF, Chaves J, Mattos RW, Silveira D, Ferreira VM, Calixto JB, Santos AR (2009) Mechanisms involved in the antinociception caused by ethanolic extract obtained from the leaves of Melissa officinalis (lemon balm) in mice. Pharmacol Biochem Behav, 93, 10-16

20. Kang DS, Cho MG (2016) Antioxidant activities of mixed grains. Korean J Food Nutr, 29, 635-642

21. Folin O, Ciocalteu V (1927) On tyrosine and tryptophane determinations in proteins. J Biol Chem, 73, 627-650

22. Hong JI, Kim HJ, Kim JY (2011) Factors affecting reactivity of various phenolic compounds with the folin-ciocalteu reagent. J Korean Soc Food Sci Nutr, 40, 205-213

23. Blois MS (1958) Antioxidant determinations by the use of a stable free radical. Nature, 181, 1199-2000

24. Casal S, Malheiro R, Sendas A, Oliveira BPP, Pereira JA (2010) Olive oil stability under deep-frying conditions. Food Chem Toxicol, 48, 2972-2979

25. Chen WA, Chiu CP, Cheng WC, Hsu CK, Kuo MI (2013) Total polar compounds and acid values of repeatedly used frying oils measured by standard and rapid methods. J Food Drug Anal, 21, 58-65

26. AOCS (2017) Determination of polar compounds in frying fats. AOCS Official Method Cd 3d-63, American Oil Chemists Society, Urbana, IL, USA

27. Lee JM, Chang PS, Lee JH (2007) Comparison of oxidative stability for the termally-oxidized vegetable oils using a DPPH method. Korean J Food Sci Technol, 39, 133-137

28. AOAC (1990) Official methods of analysis. $15^{\text {th }}$ ed, Method 969.33, Association of Official Analytical Communities, Arlington, VA, USA, p 963-964

29. Siger A, Nogala-Kalucka M, Lampart-Szczapa E (2008) The content and antioxidant activity of phenolic compounds in cold-pressed plant oils. J Food Lipids, 15, 137-149

30. Rababah TM, Hettiarachchy NS, Horax R (2004) Total phenolics and antioxidant activities of fenugreek, green tea, black tea, grape seed, ginger, rosemary, gotu kola, and ginkgo extracts, vitamin $\mathrm{E}$, and tert-butylhydroquinone. J Agric Food Chem, 52, 5183-5186

31. Kim IS, Yang MR, Lee OH, Kang SN (2011) Antioxidant activities of hot water extracts from various spices. Int J Mol Sci, 12, 4120-4131

32. Ninfali P, Mea G, Giorgini S, Rocchi M, Bacchiocca M (2005) Antioxidant capacity of vegetables, spices and dressings relevant to nutrition. Br J Nutr, 93, 257-266

33. Chang SM, Nam SH, Kang MY (2002) Screening of the antioxidative activity, antimutagenicity and mutagenicity of the ethanolic extracts from legumes. Korean J Food Sci Technol, 34, 1115-1122

34. Lee JM, Chung H, Chang PS, Lee JH (2007) Development of a method predicting the oxidative stability of edible oils using 2,2-diphenyl-1-picrylhydrazyl (DPPH). Food Chem, 103, 662-669

35. Kim YM, Jeong HJ, Chung HS, Seong JH, Kim HS, Kim DS, Lee YG (2016) Anti-oxidative activity of the extracts from Houttuynia cordata Thunb. fermented by lactic acid bacteria. J Life Sci, 26, 468-474

36. Lee SE, Kim YS, Kim JE, Bang JK, Seong NS (2004) Antioxidant activity of Ulmus davidiana var. japonica N. and Hemipteleae davidii P.. Korean J Med Crop Sci, 12, 321-327

37. Hein M, Henning H, Isengard HD (1998) Determination of total polar parts with new methods for the quality survey of frying fats and oils. Talanta, 47, 447-454

38. AOCS (2017) Determination of polar compounds in frying fats. AOCS Official Method Cd 20-91. American Oil Chemists' Society, Urbana, IL, USA

39. Son JY, Kang KO (2012) Changes in quality properties of deep frying oil and fried chickens according to frying number. J East Asian Soc Diet Life, 22, 527-534

40. MFDS (2017) Food code. Ministry of Food and Drug Safety, Cheongju, Korea, p 112-119

41. Lee JW, Park JW (2010) Changes of fatty acid composition and oxidation stability of edible oils with frying number of french fried potatoes. J Korean Soc Food Sci Nutr, 39, p 1011-1017

42. Stirton AJ, Turer J, Riemenschneider RW (1945) Oxygen absorption of methyl esters of fat acids, and the effect of antioxidants. Oil and Soap, 22, 81-83 